\title{
FILOSOFIA E POESIA EM $A$ GAIA CIÊNCIA DE NIETZSCHE
}

\author{
Alexandre Mendonça é Professor Adjunto da Faculdade de Educação da UFRJ, doutor em Filosofia pela UFRJ e mestre em \\ Filosofia pela UERJ. \\ E-mail: alexfm72@hotmail.com
}

\begin{abstract}
Resumo
Pretende-se discutir as principais estratégias utilizadas nos últimos escritos de Nietzsche para abolir as tradicionais oposições entre verdade e mentira e, consequentemente, entre filosofia e ficção.
\end{abstract}

\begin{abstract}
It is intended to discuss the main strategies used in Nietzsche's latest writings to abolish the traditional oppositions between truth and falsehood, and thus between philosophy and fiction.
\end{abstract}

Se o intenso diálogo entre a filosofia e a literatura é uma das tônicas do pensamento contemporâneo, suas origens remontam ao ambiente histórico do qual a filosofia pouco a pouco emergiu. Afinal, os chamados primeiros filósofos, longe de desenvolverem o estilo argumentativo, silogístico e dissertativo pelo qual seus sucessores passaram a se distinguir dos demais, não traziam como herança toda sorte de elementos constitutivos da poesia? E antes mesmo deles, na Grécia Arcaica, em que vigorava o regime da palavra sagrada, não cabia aos poetas o lugar de porta vozes dos deuses e, portanto, o lugar de enunciadores da incontestável Verdade? E mesmo com o processo de laicização, humanização e racionalização dos discursos que então se sucedeu, os poetas, agora ao lado de novos personagens como os sofistas e os primeiros filósofos, não continuaram exercendo tremenda influência sobre os processos de produção da verdade? É claro que a verdade, humanizada, tornara-se algo bem mais modesto. Tratava-se da verdade demasiado humana, produzida pelos homens e passível de ser contestada pelos homens. A verdade pensada como criação, como efeito da palavra persuasiva sobre o outro, como valor atribuído aos discursos e relativo a circunstâncias instáveis.

A reinvenção da verdade como algo ao mesmo tempo humano, racional e não relativo - e, por assim dizer, pretensamente absoluto - exigiu que se lançasse mão de toda a sorte de artifícios disponíveis para, a partir deles, se empreender uma verdadeira guerra contra os discursos que atravessavam a vida social naquele momento da cultura ocidental: Grécia democrática, século V A.C. Valendo-se de truques persuasivos, poéticos e dramáticos, disponíveis na cultura grega, surgem os diálogos de Platão. Graças a esses truques, tais textos, em franca rivalidade com a sofística, com a poesia, mas também com a pintura e, poderia ser dito, com aquilo que na cultura ocidental se tornou o campo das artes, forjaram para a filosofia um estatuto superior, a partir do qual aqueles discursos com os quais ela rivalizava foram desqualificados. A partir daí, e por muito tempo, mal se pode falar propriamente em diálogo entre estes campos. 
A efetiva retomada contemporânea do diálogo entre a filosofia e as artes, e a literatura, e a poesia, está diretamente ligada à contestação do gesto platônico que fundou a tradição filosófica. É neste sentido que se destaca o pensamento de Nietzsche como referência central. Não só pelo seu relativo pioneirismo, mas, sobretudo, pela radicalidade de suas estratégias e de seu diagnóstico. Ao investir contra as oposições de valor, ao dissolver as fronteiras que separariam a verdade da mentira, a essência da aparência, Nietzsche solapa as bases da tradição de pensamento que se origina a partir dos textos de Platão e abole, tanto no plano do conceito como, de modo talvez ainda mais radical, no plano do estilo ou, mais especificamente, do uso dos artifícios próprios da palavra escrita, as fronteiras que separariam a filosofia da arte, chegando mesmo a apontar para uma possível superioridade da poesia em relação ao discurso filosófico tradicional.

O que se pretende aqui é mapear e discutir os principais elementos colocados em jogo por Nietzsche para operar tal reviravolta em relação às tendências hegemônicas no pensamento ocidental, tomando como ponto de partida a publicação do livro intitulado A gaia ciência - expressão que ele então passa a utilizar livremente para nomear a singularidade de sua suposta sabedoria. Pretende-se ainda identificar em que medida e de que maneira tais elementos são desenvolvidos em seus últimos escritos.

A seção 54 de A gaia ciência, sugestivamente intitulada "A consciência da aparência", é emblemática a respeito da estratégia utilizada por Nietzsche para abalar as bases a partir das quais a tradição filosófica teria forjado a sua suposta distinção e superioridade em relação ao campo das artes e da poesia em especial. Estratégia que se evidencia a partir deste livro, e que é incorporada de modo cada vez mais radical a seus textos posteriores. O próprio estilo em que este fragmento é composto se afasta da sobriedade lógica com a qual os textos filosóficos tradicionalmente tendem a ser apresentados. Em vez de compactuar com pressupostos metafísicos ou constatações científicas para validar suas formulações, Nietzsche cria suas hipóteses a partir de inferências próprias, apresentadas de um modo um tanto poético, lançando mão da ironia e da paródia. Como se isso não bastasse, ele radicaliza seu posicionamento antidogmático e utiliza tais figuras para relativizar, de um modo sutil, o valor daquilo mesmo que afirma, assumindo, tal como um artista, o caráter puramente artificial daquilo que, através de seus textos, vem à tona:

Como é nova e maravilhosa e, ao mesmo tempo, horrível e irônica a posição que sinto ocupar com meu conhecimento, diante de toda a existência! Eu descobri que a velha humanidade e animalidade, e mesmo toda a pré-história e o passado de todo ser que sente, continua inventando, amando, odiando, raciocinando em mim - no meio deste sonho acordei repentinamente, mas apenas para a consciência de que sonho e tenho de prosseguir sonhando para não sucumbir: tal como o sonâmbulo tem que prosseguir o sonho para não cair por terra. O que é agora para mim a aparência? Verdadeiramente, não é oposto de alguma essência - que posso eu enunciar de qualquer essência, que não os predicados de sua aparência? Verdadeiramente não é uma máscara mortuária que se pudesse aplicar a um desconhecido X e depois retirar! Aparência é, para mim, aquilo 
mesmo que atua e vive, que na zombaria de si mesmo chega ao ponto de me fazer sentir que tudo aqui é aparência, fogo-fátuo, dança de espíritos e nada mais - que, entre todos esses sonhadores, também eu, o "homem do conhecimento", danço a minha dança, que o homem do conhecimento é um recurso para prolongar a dança terrestre e, assim, está entre os mestres de cerimônia da existência, e que a sublime coerência e ligação de todos os conhecimentos é e será, talvez, o meio supremo de manter a universalidade do sonho e a mútua compreensibilidade de todos esses sonhadores, e, precisamente com isso, a duração do sonho. (Nietzsche, 2001, p. 92)

Aqui, não se trata de reconhecer as ilusões metafísicas para então delas se desvencilhar em busca de certezas de outra espécie, em busca de algum conhecimento seguro. A única certeza por ele admitida é a de que, inevitavelmente, se vive e se precisa viver no domínio da ilusão - o que, por sua vez o leva a colocar em jogo a possibilidade de também esta certeza não passar de mais uma ilusão necessária à vida. Recusando a possibilidade de o conhecimento escapar de seu caráter necessariamente onírico, faz da própria tomada de consciência a respeito do caráter aparente e ilusório de toda consciência algo que também já não se distingue e não quer ser distinguido da ilusão. Afinal, crer haver despertado pode equivaler a estar se deixando levar por outro sonho. Acordamos de um sonho ou sonhamos que acordamos? Parece que Nietzsche pretende escapar radicalmente de qualquer resquício de dogmatismo tornando a resposta para esta questão indecidível. Daí ele abrir o texto chamando atenção para o caráter ambíguo, ao mesmo tempo maravilhoso e horrível, de sua descoberta, chamando atenção para o posicionamento irônico que ele então acredita que o conhecimento ocupe diante da existência. Longe de possibilitar que nos libertemos dos erros e enganos, longe de nos fornecer alguma espécie de certeza, o conhecimento - seja lá em que modalidade for, metafísico, científico - não seria outra coisa senão um instrumento para manter a universalidade do sonho. Paradoxalmente, dentre as ilusões necessárias que constituem o mundo onírico em que vivemos estariam as crenças nas mais diferentes modalidades de verdade produzidas pelo conhecimento - dentre elas, a crença nas verdades pretensiosas da metafísica, a crença nas verdades modestas das ciências, e por que não? - a própria crença na "universalidade" e na "necessidade" da ilusão. O que há de paradoxal e irônico nesta perspectiva assumida por Nietzsche é que ela não pode ser afirmada sem assumir-se também como necessariamente ilusória e, ainda, como ilusoriamente necessária.

Com isso, esta passagem evidencia uma característica marcante de vários dos textos que Nietzsche passa a compor a partir de A gaia ciência: a recorrência a procedimentos que relativizam ou mesmo suspendem o sentido daquilo mesmo que eles afirmam. Muitas vezes Nietzsche constrói argumentos que desembocam em conclusões paradoxais que, se afirmadas de um modo radical, se levadas às últimas conseqüências, acabam por negar sua própria validade, suspendendo assim o valor de verdade que muitas vezes tendemos a lhes atribuir, como neste caso, em que, a partir da afirmação radical da tese que propõe a "necessidade" e "universalidade" da aparência, chega-se não só à negação da concepção dogmática de verdade, como também à suspensão do 
valor de verdade desta mesma tese, que, com isso, livra a si mesma de qualquer resquício de dogmatismo. Neste sentido outro texto que parece exemplar a respeito da utilização deste tipo de artifício antidogmatizante por excelência é o que constitui a seção 84 de $A$ gaia ciência, no qual Nietzsche discute as origens da poesia. Ao final do texto ele procura chamar atenção para o poder persuasivo que irradia de artifícios como a rima e a métrica, e que, em determinados momentos históricos teria acabado por conferir efeito de verdade aos enunciados poéticos. Neste texto, referindo-se mais especificamente ao regime da palavra sagrada na Grécia Arcaica, no qual o poeta funcionava como mestre da verdade, por ser tido como porta voz dos deuses, Nietzsche trata a poesia como uma mentira persuasiva, que teria obtido efeito de verdade por encantar seus interlocutores com a musicalidade que dela emana. A partir daí, ele parece zombar, com evidente ironia, do fato de os filósofos mais sérios recorrerem a citações de poetas para fortalecerem seus pensamentos e, curiosamente, conclui o texto justamente com um verso atribuído a Homero, que confirmaria esta associação da poesia à mentira:

Não é divertido que mesmo os filósofos mais sérios, normalmente tão rigorosos em matéria de certezas, recorram a citações de poetas para dar força e credibilidade a seus pensamentos? - e, no entanto, uma verdade corre mais perigo quando um poeta a aprova do que quando a contradiz! Pois, como diz Homero: "Os poetas mentem demais". (Nietzsche, 2001, pp. 111-112)

É evidente aqui a ironia embutida na aparente contradição de finalizar o argumento aderindo justamente ao gesto do qual ele parecia zombar quando o associava aos filósofos "mais sérios" e ávidos por "certezas". Ironia que se torna ainda mais intensa quando se leva em conta que, ao longo de todo o livro, está presente não só certo elogio à poesia como também a intensa utilização de elementos poéticos que passam a marcar o texto nietzschiano e se afinam intensamente com o abandono do pathos da seriedade e da dogmática pretensão de se alcançar certezas definitivas. Estas ideias que não só vinculam os textos de Nietzsche à poesia, como ainda explicitam a vinculação da poesia com o que seria certa modalidade da mentira - modalidade que se afirma como mentira - são retomadas no capítulo "Dos poetas", em Assim falou Zaratustra, através de enunciados que colocam em jogo um procedimento análogo ao referido acima:

"Mas o que foi que, um dia, te disse Zaratustra? Que os poetas mentem demais? Mas também Zaratustra é um poeta. Acreditas, agora, que, nisso, ele falou a verdade? Por que acreditas?" O discípulo respondeu: "Eu creio em Zaratustra". Mas Zaratustra meneou a cabeça e sorriu. "A mim, a fé não me beatifica" - disse -, "mormemente a fé em mim. Mas admitamos que alguém tenha dito, com toda a seriedade, que os poetas mentem demais: ele tem razão - nós mentimos demais". (Nietzsche, 1998, p.158)

$\mathrm{Na}$ contramão de todo dogmatismo, Nietzsche deliberadamente se afasta do pathos da seriedade, e da pretensão de veicular certezas, de suscitar fé e de arrebanhar discípulos fiéis, criando um jogo poético, em forma de círculo vicioso, no qual 
paradoxos remetem a parodoxos ad infinitum. Se o leitor toma como uma verdade absoluta, como uma certeza digna de ser levada a sério, a ideia de que "os poetas mentem demais", ele é por isso mesmo incitado a dela desconfiar, ou até mesmo a aderir a uma perspectiva a ela oposta, ao perceber que ela teria sido veiculada por um poeta (Homero, Zaratustra, Nietzsche, pouco importa) e, portanto, por um possível mentiroso. Se o poeta é um mentiroso, não estaria ele mentindo ao se afirmar como mentiroso? E, se ele estiver mentindo, poderíamos concluir que ele é o oposto do que diz ser? Poderíamos concluir que ele é um "homem veraz"? Neste caso, seríamos levados a novamente aceitar a tese de que os poetas mentem, já que ela teria sido veiculada por um possível "homem veraz" que, no entanto, talvez minta ao se dizer mentiroso. Ou, em vez disso, seria a afirmação da mentira a única verdade que se poderia esperar de um poeta mentiroso por excelência? Configura-se assim um círculo vicioso que não nos permite alcançar qualquer certeza, que afasta qualquer espécie de respostas definitivas e mantém tais questões no campo do indecidível.

É justamente este tipo de procedimento que está sendo utilizado na seção 54 de A gaia ciência. Quando aí propõe a tese da "universalidade" e da "necessidade" da aparência e da ilusão Nietzsche está provocativamente nos convidando a relativizar o valor desta mesma tese, a tomá-la como também aparente e ilusória, e não como necessária ou universal. As ideias de "universalidade" e de "necessidade" não aparecem aí tal como no pensamento dogmático. Nietzsche delas faz um uso evidentemente poético, irônico e paródico, que subverte o sentido convencional por elas assumido quando veiculadas pela tradição filosófica.

Longe de compreender a aparência como oposto negativo de uma suposta essência, de alguma "coisa em si", ou como uma máscara, que ocultaria uma realidade mais fundamental incógnita, ao afirmar a universalidade e a necessidade da aparência e da ilusão, através desta espécie de jogo discursivo, Nietzsche está radicalizando o gesto pelo qual dissolve as oposições de valores metafísicos. A estratégia efetivamente adotada pelo texto aqui em questão é muito mais a de, por um lado, ignorar, desconsiderar a suposição da existência de um além-mundo, de um "mundo verdadeiro", em vez de atacá-la diretamente, e, por outro, se apoiar justamente na categoria tradicionalmente desqualificada - a categoria da aparência, da ilusão - para então, "universalizá-la", generalizá-la, ampliar o seu sentido a ponto de ela passar mesmo a incluir em si tudo aquilo que até então se supôs ser a ela oposto. É como mera conseqüência desta plena reafirmação das figuras negativizadas pela metafísica que os elementos tradicionalmente valorizados como primeiros e superiores são indiretamente desmistificados, surgindo então como subconjuntos, ou como efeitos daqueles que agora ocupam uma posição privilegiada. Se tudo é aparência, a própria ideia de verdade só pode ser pensada como uma modalidade, como um efeito da ilusão. E como uma modalidade ou como um efeito que, paradoxalmente, se torna tão mais ilusório quanto mais se pretende passar por oposto ao campo das puras aparências, tão mais falso quanto mais se pretende passar por "verdadeiro". A concepção da vida e do próprio 
conhecimento como instâncias que se movem no âmbito exclusivo das aparências instaura um regime de pensamento no qual aparências remetem a aparências, possibilitando que se tome qualquer suposição de verdade como um mero efeito desse jogo ao qual Nietzsche empresta uma imagem tão estética quanto instável.

Ao investir na potencialização do próprio conceito de aparência, ao se valer deste conceito para designar não algo de inferior e secundário em relação a um plano de realidade superior, mas sim o que seria necessariamente o único plano de realidade existente, emprestando a tal conceito um sentido bastante diferente daquele consagrado pela tradição de pensamento metafísico, Nietzsche está não só abolindo os limites que separariam o "mundo verdadeiro" do "mundo aparente", mas também os limites que tradicionalmente separariam a filosofia das demais atividades com as quais ela teria rivalizado desde sua origem socrática ou platônica. Se, desde seu momento inaugural, a filosofia metafísica teria se constituído reivindicando para si o estatuto de terreno próprio para o exercício do pensamento, o estatuto de um modo de pensamento privilegiado a partir do qual se poderia ascender ao suposto "mundo verdadeiro", se, desde então, a filosofia teria afirmado sua superioridade à custa da desqualificação moral e ontológica de outros discursos que gozavam de certa importância na cultura grega - a sofística e a poesia, em especial, mas também a pintura e as artes em geral que teriam passado a ser tratados como meramente aparentes e até mesmo enganosos e, portanto, nocivos ao conhecimento, por outro lado, a ideia nietzschiana da universalidade e da necessidade da aparência, a concepção da vida e do próprio conhecimento no âmbito exclusivo das aparências desmonta, de um modo radical, as bases a partir das quais esta tendência acabou por se lançar e por se tornar hegemônica na cultura ocidental. Uma vez que não haveria realidade para além do campo constituído por puras aparências, uma vez que o conhecimento, como parte integrante deste jogo estético que compõe a vida, não seria capaz de fornecer mais que aparências, uma vez que a própria verdade não seria outra coisa senão mais um efeito aparente efeito tão mais ilusório quanto menos o supomos -, já não se sustenta a tradicional oposição entre o que seria o campo da filosofia e o que seria o campo das artes em geral. Surge, assim, a possibilidade de, por um lado, se pensar a arte, a literatura, ou, mais especificamente ainda, a poesia como instâncias primeiras em relação à filosofia, e, por outro, a possibilidade de se pensar tudo o que até então teria sido designado pela palavra "filosofia" como forma velada de arte, de literatura, de poesia, como efeito de certa modalidade de discurso hoje dito ficcional, que se vale dos seus artifícios poéticos, dramáticos e persuasivos, para se voltar contra o próprio campo da arte e, assim, erigir a ilusão da constituição de um terreno próprio ao pensamento que se pretende superior e oposto a tudo aquilo que estaria em sua própria origem. Possibilidade que Nietzsche passa a explorar intensamente, em várias vertentes, a partir de A gaia ciência.

Um dos sinais mais evidentes desta aliança que Nietzsche volta a estabelecer com a arte - especialmente com a poesia - dissolvendo a suposta oposição entre o que tradicionalmente se convencionou como sendo o campo da filosofia e o que se 
convencionou como sendo o campo da ficção, é a própria apresentação de sua filosofia como "gaia ciência". A noção de "gaia ciência" surge em sua obra quando ele a escolhe para batizar o livro, aqui em questão, publicado em 1882. Vale observar que a expressão "a gaia ciência" não é simplesmente a tradução habitualmente aceita para a expressão alemã "Die fröliche Wissenschaft" - que é o título original do livro. "Die fröliche Wissenschaft" já é a tradução alemã escolhida por Nietzsche para a expressão provençal "la gaya scienza". Expressão que, por sua vez, ele não só adota como subtítulo para o referido livro como parece mesmo preferir, ao lado da alternativa "gai saber", em relação à tradução alemã, nas diversas vezes que a tal noção se refere ao longo de sua obra. Se, por um lado, ele usa "Die fröliche Wissenschaft" como título, por outro, faz questão de guardar certa distância em relação a este termo, sublinhando sempre sua origem.

Isto não é gratuito. "Gaya scienza" ou "gai saber", originalmente, não se referem à ciência tal como hoje ainda a entendemos e que, em alemão, é designada por "Wissenschaft". Tais termos se referem a um saber específico dos trovadores provençais, que diz respeito tanto ao conteúdo do que é entoado em seus poemascanções quanto à própria técnica requerida para sua composição e execução. Nietzsche, ao longo de sua obra, faz questão de estabelecer e explorar a seu favor o possível vínculo entre sua "gaia ciência" e as criações poéticas e musicais dos trovadores provençais. No que diz respeito mais especificamente à aliança estabelecida entre a gaia ciência nietzschiana e a arte provençal, talvez as evidências mais fortes deste enlace surjam nos sessenta e três poemas compostos para abrir o livro aqui em questão, ou ainda nas canções publicadas como apêndice à sua segunda edição. Em Ecce Homo, ao referir-se a tais canções, Nietzsche, de um modo astuto, afirma:

As Canções do príncipe Vogelfrei, compostas em grande parte na Sicília, lembram explicitamente a noção provençal de gaya scienza, aquela unidade de trovador, cavaleiro e espírito livre com que a maravilhosa cultura dos provençais se distingue de todas as culturas equívocas; o último poema especialmente, "Ao Mistral", um radiante canto-dança em que - permitam-me - bailo sobre a moral, é um perfeito provençalismo. (Nietzsche, 1995, p.81)

Ao apontar para a origem de sua "gaia ciência", Nietzsche procura não só reforçar a aliança por ele produzida entre seu pensamento e a "cultura maravilhosa dos provençais", como, através dela, distinguir-se de "todas as culturas equívocas". Daí talvez referir-se ao termo "fröliche Wissenschaft" até mesmo de um modo irônico, como na seção 293 de Além do bem e do mal. Neste texto, contra o culto do sofrimento e da compaixão que estariam no bojo da decadente cultura européia, Nietzsche receita o potente "amuleto do gai saber" - e aí acrescenta, entre travessões: "fröliche Wissenschaft, para que os alemães possam me entender" (Nietzsche, 1992, p. 194-195). Ele sugere, assim, uma relativa distância entre a "gaya scienza" e sua cultura natal. Por outro lado, ao traduzir a expressão "gaya scienza" para o alemão, Nietzsche empresta à 
ciência [Wissenchaft] uma leveza e certo gosto jocoso pela artificialidade que a ela não seriam próprios. Estabelecendo uma aliança com a arte "zombeteira, leve, fluida, divinamente livre e artificial", como adverte o prefácio do livro em questão (Nietzsche, 2001, p.14), Nietzsche procura criar para sua filosofia outra imagem, distante do peso e da seriedade que ele identifica na decadência da cultura filosófica, moral e religiosa européia - decadência da qual, para Nietzsche, a cultura alemã seria o signo máximo. Se as formas de conhecimento privilegiadas pela cultura ocidental - seja a religião, seja a filosofia metafísica, seja a ciência ou mesmo certa modalidade de arte - teriam tomado a verdade como valor superior, a gaia ciência nietzschiana, ao escapar deste modo de pensamento, afirma a universalidade e a necessidade da aparência, da ilusão, apresentando suas formulações cada vez mais num estilo poético e até mesmo dramático, que se sintonizam perfeitamente com sua intenção de afirmar e de não ocultar o caráter meramente hipotético das ficções colocadas em jogo pelo funcionamento da razão.

Esta tendência não só é incorporada a seus escritos posteriores, como neles é muitas vezes radicalizada. A seção 34 de Além do bem e do mal é especialmente significativa neste sentido, por estabelecer um forte vínculo de continuidade com o posicionamento assumido a respeito do conhecimento em A gaia ciência - o que fica claro já em suas linhas iniciais:

não importando o ponto de vista filosófico em que nos situemos hoje: o caráter errôneo do mundo onde acreditamos viver é a coisa mais firme que nosso olho ainda pode apreender:- para isso encontramos muitas e muitas razões, que gostariam de nos induzir a conjecturas sobre um enganador princípio na "essência das coisas". (Nietzsche, 1992, p. 40)

O texto prossegue sugerindo que o fato de se reconhecer o caráter ilusório do pensamento deveria levar à suspeita a respeito do que quer que dele surgisse e, portanto, à inviabilização da crença em qualquer espécie de "certezas imediatas". O argumento utilizado para isso é o de que tal crença não passaria de uma ingenuidade moral, ou de uma estupidez nada honrosa para aqueles que pretendem se lançar para além da moral. Logo em seguida, após defender a ideia de que o filósofo, por ser a criatura mais ludibriada na face da Terra, com suas crenças ingênuas, teria o direito e o dever "da desconfiança, do olhar oblíquo e malicioso a partir de abismos de suspeita", Nietzsche aparentemente recua, pede desculpas pelo que então não passaria de uma brincadeira e avança reapresentando, a título de mera hipótese, é claro, sua concepção da vida como puro jogo de aparências:

Perdoem-me a brincadeira dessa caricatura e expressão sombria: pois eu mesmo aprendi a avaliar de outra maneira o enganar e o ser enganado, e guardo ao menos alguns socos para a fúria cega com que os filósofos resistem a ser enganados. Por que não? Não passa de um preconceito moral que a verdade tenha mais valor que a aparência; é inclusive a suposição mais mal demonstrada que já houve. Admita-se ao menos o seguinte: não existiria nenhuma vida, senão com base em avaliações e aparências perspectivas; e se 
alguém, com o virtuoso entusiasmo e a rudeza de tantos filósofos, quisesse abolir o "mundo aparente", bem, supondo que vocês pudessem fazê-lo - também da sua verdade não restaria nada! Sim, pois o que nos obriga a supor que há uma oposição essencial entre "verdadeiro" e "falso"? Não basta a suposição de graus de aparência, e como que sombras e tonalidades do aparente, mais claras e mais escuras, - diferentes valeurs [valores] para usar a linguagem dos pintores? Porque não poderia o mundo que nos concerne - ser uma ficção? E a quem faz a pergunta; "mas uma ficção não requer um autor?" - não se poderia replicar: Por quê? Esse "requer" não pertenceria também à ficção? (Nietzsche, 1992, pp. 41-42)

Zombando da fúria cega com que os filósofos resistem a ser enganados, Nietzsche coloca em xeque a preconceituosa suposição moral de que a verdade teria mais valor que a aparência, e propõe que se admita ao menos a hipótese de que o caráter meramente perspectivo de nossa avaliações seria um elemento necessário à constituição e ao funcionamento da vida. Entra em jogo mais uma vez a ideia de que a vida poderia ser concebida no âmbito exclusivo das aparências, de que o ilusório e o perspectivo seriam necessários à vida.

Fica claro nesta passagem que a referida secção de Além do bem e do mal retoma plenamente a concepção da vida e do conhecimento no âmbito exclusivo das aparências, a concepção do "mundo aparente" como único plano de realidade existente a partir do qual teriam sido forjadas as chamadas verdades. Recusando a ideia de que entre o verdadeiro e o falso haveria uma oposição essencial, Nietzsche abre a possibilidade de se pensar a verdade como um mero efeito criado a partir de um jogo de aparências.

Adotando a forma interrogativa - forma absolutamente conveniente ao antidogmatismo do qual a gaia ciência nietzschiana pretende ser porta voz - Nietzsche não deixa de propor que em vez de se supor a existência de uma oposição essencial entre o verdadeiro e o falso, se adote a suposição da existência "de graus de aparência, e como que sombras e tonalidades do aparente, mais claras e mais escuras, diferentes valeurs". Valendo-se de uma metáfora pictórica, utilizando um termo próprio à linguagem dos pintores (valeurs) para designar diferenças de tonalidade, mais ou menos saturadas, ele suspende a validade da oposição entre o "verdadeiro" e o "falso" e nos convida a pensar a realidade como um campo constituído estritamente por aparências, que, longe de se equivalerem, se diferenciam uma das outras por contraste, mais ou menos intensos e perceptíveis, compondo uma imagem que acolhe um amplo espectro de múltiplas variações de luminosidade de tonalidades e de sombras. Esta imagem estética que Nietzsche compõe para a existência, incorporando ao texto filosófico metáforas e expressões que remetem ao campo da pintura - artimanha especialmente expressiva, já que se trata de pensar a vida no âmbito das aparências - se desdobra ainda na sugestão, também apresentada na forma interrogativa, de que o "mundo que nos concerne" não passaria de uma ficção, e de uma ficção sem autor ou, quando muito, de uma ficção que nos levaria a forjar a imagem de um autor.

Se Além do bem e do mal estabelece uma linha de continuidade direta com as formulações que surgem em A gaia ciência, Crepúsculo dos ídolos fornece a melhor 
síntese do posicionamento assumido por Nietzsche nestes escritos a respeito da relação entre o "mundo aparente" e do "mundo verdadeiro". Não é ã toa que, ao comentar o titulo do livro em Ecce Homo, ele faz a seguinte observação: "O que no título se chama ídolo é simplesmente o que até agora se denominou verdade. Crepúsculo dos ídolos leia-se: adeus à velha verdade" (Nietzsche, 1995, p. 99). Neste livro, a dissolução da suposta oposição entre o "verdadeiro" e o "falso" assume um papel central, sendo levada ao ponto extremo em que a verdade se converte de uma vez por todas em uma fábula.

Os primeiros indícios da continuidade estabelecida com a revalorização das aparências empreendida primeiramente por A gaia ciência surgem no capítulo "A razão na filosofia", em que o primado do "mundo aparente" em relação ao "mundo verdadeiro" é reafirmado insistentemente. A seção 2 deste capítulo traz uma máxima que não só retoma a ideia de se conceber a realidade como algo puramente aparente, como, a partir daí, explicita a ideia, ainda implícita na seção 54 de A gaia ciência, de que o mundo verdadeiro não passaria de um efeito acrescentado pela "mentira" ao campo das aparências. Tudo se passa como se Nietzsche concebesse a verdade como uma modalidade da aparência que, além de não se afirmar como tal, procura passar por oposta ao próprio plano de realidade do qual ela se origina: "o mundo 'aparente' é o único, o 'mundo verdadeiro' é somente um acréscimo mentiroso" (Nietzsche, 2006, p. 26). A seção 6 do mesmo capítulo de Crepúsculo dos ídolos funciona como mais uma reiteração de sua posição a respeito tanto de sua concepção do "mundo aparente" como realidade primeira, como da conclusão que daí decorre de que o "mundo verdadeiro" não seria mais do que uma criação forjada posteriormente a partir da única realidade existente: “As razões pelas quais 'este' mundo é designado como aparente fundam, antes, sua realidade - um outro tipo de realidade é absolutamente indemonstrável. (...) Construiu-se o "mundo verdadeiro" a partir da contradição com o mundo real: um mundo aparente, sem dúvida, na medida em que é apenas uma ilusão moral e óptica" (Nietzsche, 2006, p. 29).

Como já foi indicado, é claro que uma das possíveis conseqüências destas formulações que afirmam a universalidade da aparência, a anterioridade do "mundo aparente" em relação à ficção de um "mundo verdadeiro" é a de que também elas pertencem ao campo da aparência, de modo que, caso elas venham a ser tomadas como verdades, isto se deve antes aos efeitos do poder persuasivo que as sustenta, se deve aos artifícios pelos quais a "mentira" posteriormente converte o que a princípio teria valor de pura aparência naquilo que aparentemente passa a ter valor de verdade. Paradoxalmente, a própria tentativa de refutação de tais formulações acaba por potencializar ainda mais a força persuasiva que delas emana, fortalecendo, assim, a ilusão da veracidade por elas suscitada. Negar a veracidade destes enunciados a partir do que eles mesmos afirmam, além de pressupor uma adesão prévia a seus conteúdos, ainda produz o efeito de reforçá-los. Tomá-los como meramente aparentes é confirmar a possibilidade de tudo não passar mesmo de mera aparência. Quer os tomemos como 
verdadeiros, quer os tomemos como falsos, estamos presos nas malhas dessa trama que Nietzsche desenvolve pelo menos desde A gaia ciência e estende até seus últimos escritos.

Contudo, embora, com este gesto, Nietzsche abandone a possibilidade de utilizar as categorias da verdade e da mentira como parâmetros de avaliação, embora crie certa equivalência entre o que seria verdade e o que seria a mentira, remetendo ambas as categorias ao campo das aparências; embora conceba o mundo no âmbito exclusivo das aparências, às quais inevitavelmente se atribui um mesmo estatuto ontológico, isto não significa, que esteja abolida a possibilidade de se investir em outras possibilidades de avaliação que partam de critérios não propriamente ontológicos. A terceira e a quarta proposições da secção 6 do capítulo a "Razão na filosofia" de $O$ crepúsculo dos ídolos, além de reafirmarem a suposição de que o mundo aparente seria o único plano de realidade existente, constituindo-se numa realidade primeira, a partir da qual teria sido forjada a mentira de um mundo verdadeiro, apontam para a possibilidade de se eleger um outro critério pelo qual se poderia distinguir as invenções colocadas em jogo pela filosofia metafísica, pelo cristianismo, das invenções colocadas em jogo pelo artista trágico, por exemplo:

Terceira proposição. Criar a fábula de um mundo diverso desse não tem sentido algum se pressupusermos que um instinto de calúnia, de amesquinhamento, de suspeição de vida não exerce poder sobre nós. Neste último caso, vingamo-nos da vida com a fantasmagoria de uma "outra" vida "melhor"

Quarta proposição. Cindir o mundo em um mundo "verdadeiro" e um mundo "aparente", seja do modo cristão, seja do modo kantiano (um cristão pérfido, no fim das contas) é apenas uma sugestão de décadence: um sintoma da vida que decai... O fato de o artista avaliar mais elevadamente a aparência do que a realidade não é nenhuma objeção contra essa proposição. Pois a "aparência" significa aqui uma vez mais a realidade, só que sob a forma de uma seleção, de uma intensificação, de uma correção... $\mathrm{O}$ artista trágico não é nenhum pessimista. Ele diz sim a tudo que é digno de questão e passível mesmo de produzir horror, ele é dionisíaco... (Nietzsche, 2006, p.29)

Ao, por um lado, interpretar a criação do "mundo verdadeiro" engendrada pela filosofia metafísica, pela filosofia crítica ou pelo cristianismo como um sintoma da vontade de vingança contra o mundo real, como um sintoma de decadência, e, por outro, identificar a origem da criação das aparências artísticas a um sentimento afirmativo, capaz de investir na exaltação da realidade, mesmo no que ela teria de terrível e questionável, Nietzsche explicita os critérios de avaliação dos quais agora passa a dispor: trata-se de critérios de caráter afetivo/fisiológico. Se tudo é ilusão, se tudo é invenção, lhe interessa diagnosticar que tipo de afeto estaria por trás de tais aparências, que tipo de vida: seriam afetos afirmativos, próprios de uma vida plena, forte, saudável, ou afetos negativos, próprios de uma vida decadente? Eis o tipo de avaliação que Nietzsche passa então a desenvolver nestes escritos.

Não é propriamente por se tratar de uma invenção que Nietzsche ataca a suposição idealista de existência de um "mundo verdadeiro". O que ele diagnostica e 
avalia como algo de negativo são as motivações de caráter afetivo, vital, que estariam por trás deste tipo de invenção. Segundo tal perspectiva as correntes de pensamento que Nietzsche qualifica como idealistas teriam sua origem num tipo de vida decadente, incapaz de afirmar os aspectos constitutivos do mundo aparente em que inevitavelmente vivemos. Ele interpreta, assim, a ficção de um "mundo verdadeiro" oposto ao aparente como sintoma desta impotência, como forma velada de se vingar da realidade. Tudo se passa como se, movida pelo rancor, a tradição filosófica tivesse sido primeiramente levada, a negar, a desqualificar o mundo aparente. Em seguida, ainda movida pela vontade de vingança, tal tradição teria criado a ficção de outro mundo em contraposição ao primeiro, outro mundo que, por se opor ponto por ponto ao mundo aparente então desqualificado, acaba por ser valorizado positivamente como superior, já que ele é compreendido como oposto absoluto do primeiro. Segundo este diagnóstico, a própria valorização positiva da verdade, do mundo superior, dos ideais em geral, resultaria de um gesto no qual não tomaria parte nenhum afeto afirmativo. Este gesto, quando muito, não colocaria em jogo mais que um mentiroso arremedo de afirmação. Nietzsche identifica, assim, o papel que a negatividade teria desempenhado no funcionamento deste modo de pensar por ele qualificado como idealista. Negatividade a princípio afetiva e vital, que, posteriormente, se infiltra no campo do pensamento e engendra uma lógica calcada nas oposições de valores.

Por outro lado, as ficções colocadas em jogo pela arte, pela literatura, pela poesia estariam ligadas a uma disposição afetiva absolutamente diferente. Longe de experimentar qualquer sentimento negativo em relação ao mundo em que vivemos, o artista, tal como valorizado por Nietzsche, seria aquele que, a partir da superabundância de forças vitais, é capaz de afirmar mesmo os aspectos mais terríveis e problemáticos deste mundo. Suas criações artísticas, longe de desqualificarem os aspectos constitutivos do mundo aparente, cumpririam o papel de realçar tais aspectos, intensificá-los. As invenções colocadas em jogo por tal sorte de artistas, em vez de procurarem mascarar seu aspecto ficcional, à moda idealista, ostentariam seus artifícios, potencializando assim o caráter inevitavelmente ilusório próprio ao mundo aparente em que vivemos. A arte, compreendida aqui como ficção que se assume como ficção, como aparência que se assume como aparência, se evidencia então como uma instância eminentemente afirmativa.

Por esta perspectiva podemos compreender melhor o sentido da aliança que Nietzsche procura estabelecer com a arte em geral, com a literatura, já que a filosofia toma a palavra como matéria de expressão, ou, mais especificamente ainda, com a poesia: trata-se de dar vazão ao pathos afirmativo que ele associa ao movimento de seu pensamento e de, ao mesmo tempo, afastar-se da possibilidade de contágio com o pathos negativo que teria preponderado ao longo da tradição filosófica.

Estas tematizações que se desenvolvem no capítulo "A razão na filosofia", de o Crepúsculo dos ídolos, e lançam a possibilidade de se interpretar o mundo verdadeiro como uma ficção forjada a partir de uma rancorosa, vingativa e impotente contradição 
com o mundo real, preparam as bases a partir das quais se estrutura o capítulo seguinte e, nele, talvez atinjam o ápice de sua radicalidade. Trata-se de um pequeno texto intitulado "Como o mundo verdadeiro se tornou uma fábula". A própria relação que se estabelece entre o título e o subtítulo - "A história de um erro" - dados a este texto, já funciona como comentário e prenúncio do que ali se desenrola. Partindo da perspectiva de que aquilo que, ao longo da tradição filosófica, foi designado por "mundo verdadeiro" teria sua origem em uma ficção moral, Nietzsche cria uma caricatura do que teria sido a história do erro de se deixar levar por tal ficção que, por um tempo, teria conseguido se fazer passar por oposta ao próprio plano de realidade que lhe serviria de origem. Nietzsche seleciona algumas das principais máscaras que teriam dado suporte a este velho ideal ao longo da história, destacando e reforçando alguns de seus traços característicos. Tomando a invenção platônica do "Mundo das Ideias" como ponto de partida, ele desenvolve a história deste erro, com suas metamorfoses, em seis itens, até desembocar na supressão tanto do "mundo verdadeiro" como da concepção de origem platônica do que seria o "mundo aparente", com que a tradição teria caluniado a realidade:

1. O mundo verdadeiro, acessível ao sábio, ao piedoso, ao virtuoso; este vive nele, é ele. (Forma mais velha da ideia, relativamente inteligente, simples, convincente. Transcrição da frase 'Eu, Platão, sou a verdade').

2. O mundo verdadeiro, inacessível por agora, mas prometido ao sábio, ao piedoso, ao virtuoso ('ao pecador que faz penitência').

(Desenvolvimento da ideia: torna-se mais subtil, mais insidiosa, inapreensível - tornase mulher, torna-se cristã ...).

3. O mundo verdadeiro, inacessível, indemonstrável, mas já pensado como uma consolação, um dever, um imperativo.

(No fundo, o velho sol, mas dissimulado pela névoa e pelo cepticismo; a ideia tornou-se sublime, pálida, nórdica, regiomontana.)

4. O mundo verdadeiro - inatingível? De qualquer modo, não alcançado. E enquanto não alcançado, também desconhecido. Por conseguinte, nem sequer consolador, salvador, imperativo: como é que algo desconhecido poderia obrigar?...

(Manhã cinzenta. Primeiro bocejo da razão. Canto de galo do positivismo.)

5. O 'mundo verdadeiro' - uma ideia que já não é útil para nada, e também já não é imperativa - uma ideia que se tornou supérflua, prescindível; por conseguinte, uma ideia refutada: toca a eliminá-la!

(Dia claro; pequeno almoço; retorno do bon sens e da serenidade; rubor de Platão; alvoroço endiabrado de todos os espíritos livres.)

6. O mundo verdadeiro foi por nós destruído: que mundo resta? Talvez o aparente? ... Mas não! Com o mundo verdadeiro destruímos igualmente o aparente!

(Meio-dia; momento da sombra mais curta; fim do mais longo erro; culminação da humanidade; INCIPT ZARATHUSTRA). (Nietzsche, 2006, pp. 31-32)

Tendo sido criado em oposição ao mundo real, material, sensível, num primeiro momento, o "mundo verdadeiro" teria permanecido acessível apenas ao filósofo, tipo privilegiado por Platão, a quem caberia a tarefa de ascender ao plano de transcendência; com o cristianismo, que teria traduzido o platonismo para o povo, o mundo verdadeiro passaria a ser acessível ao "pecador que faz penitência"; Kant seria aquele através de 
quem este mundo passa a ser reconhecido como inatingível pelo conhecimento teórico, tornando-se, porém, acessível através de um imperativo moral. Por fim, com o deslocamento levado adiante pelas tendências positivistas, que conduzem a verdade do campo da transcendência para o campo do que, em linguagem kantiana, não passaria de realidade fenomênica, a suposição da existência de um tal "mundo verdadeiro" agoniza até ser desmistificada pelos espíritos livres como uma mera ficção colocada em jogo para atender a fins morais - daí o uso do termo "fábula" - e, assim, proporcionar a conservação de um certo tipo de vida - a saber, um tipo de vida impotente, que vingativamente se volta contra o mundo aparente em que vivemos.

Embora o último dos seis itens que compõem este texto sentencie que, com a destruição do mundo verdadeiro, teria sido igualmente destruído o mundo aparente, isto não significa que Nietzsche esteja recusando ou superando a concepção da vida no âmbito exclusivo das aparências, a ideia de que as aparências se constituiriam numa instância de primeira ordem, desenvolvida em livros anteriores e retomada no capítulo anterior daquele mesmo livro. Isto acontece em função do diálogo direto que este texto estabelece com o platonismo, ao situá-lo na origem da história que ali é contada. Como adverte o subtítulo, o que é contada é a história de um erro. Mais especificamente, a história do erro que teria sua origem no platonismo: o erro embutido na crença na existência de um "mundo verdadeiro" concebido como oposto ao "mundo aparente", de um "mundo verdadeiro" tomado como instância primeira, em relação à qual o "mundo aparente" não passaria de um pálido reflexo, imperfeito e nocivo ao conhecimento. Quando Nietzsche afirma que, com a destruição do "mundo verdadeiro" teria sido destruído também o mundo aparente, tanto a expressão "mundo verdadeiro", quanto a expressão "mundo aparente" estão sendo utilizadas com o mesmo sentido que elas assumem segundo a tradição de pensamento filosófico de origem socrático-platônica. $\mathrm{O}$ que ele destrói é o mundo verdadeiro tal como compreendido pelo platonismo. Conseqüentemente, se, pela perspectiva platônica é, a partir do mundo verdadeiro que se pode pensar o mundo aparente, a supressão do primeiro implica a supressão do segundo. Abole-se também o "mundo aparente", mas abole-se o "mundo aparente" concebido como um segundo e inferior plano da realidade. Por outro lado, é mantida a possibilidade de se atribuir à expressão "mundo aparente" outro sentido que já não funcione como uma calúnia contra a realidade, a possibilidade de se desenvolver outra concepção do que seriam as aparências. Possibilidade que, como vimos, é insistentemente explorada não só em livros anteriores, mas no próprio Crepúsculo dos idolos.

É apenas a partir da ideia nietzschiana de que o "mundo verdadeiro" não passa de uma modalidade da aparência, de que aquilo que se toma por "verdadeiro", longe de se constituir numa realidade em si, originária, não passa de efeito de uma mentira com forte poder persuasivo, de que a crença numa oposição essencial entre o "mundo verdadeiro" e o "mundo aparente" seria um erro, é a partir daí que se pode contar a história deste erro tal como narrada por Nietzsche. Se nos perguntarmos pelo 
responsável pela conversão do mundo verdadeiro em fábula, a resposta evidente é: Nietzsche. É escrevendo o pequeno texto intitulado "Como o mundo verdadeiro se tornou uma fábula", que Nietzsche converte o "mundo verdadeiro" em fábula. Conversão realizada através de um texto que incorpora, de um modo mais que evidente, ostensivo mesmo, elementos artísticos, poéticos e dramáticos. Além do tom caricatural, hiperbólico, que atravessa todo o texto, além dos personagens que Nietzsche recria em poucas palavras, os comentários entre parênteses funcionam não apenas como observações conceituais, filosóficas, mas também como rubricas, como marcações cênicas que indicam as ações dos personagens e mesmo as variações de luz e cenário que se dão enquanto esta trama se desenvolve.

Mais uma vez, o texto nietzschiano não se furta a apontar para si mesmo como ficcional. Em vez disso, parece desejar fazê-lo de um modo excessivo, gritante. Se, como indicam as rubricas, Platão ruboriza, ao ser desmascarado como poeta que teria pretendido se passar por filósofo, se ele se envergonha ao ver seu mundo das ideias ser denunciado como simulacro, e sua filosofia reduzida ao estatuto de poesia dialética, socrática, os espíritos livres festejam a ruptura dos limites que separariam o "mundo verdadeiro" do "mundo aparente", a filosofia da ficção, com uma algazarra endiabrada, e, com alegria, se movem pelo campo da arte como campo próprio ao exercício do pensamento - campo do qual a filosofia jamais teria escapado, apesar de contra ele ter se voltado, apesar de seus esforços inúteis neste sentido.

Não é à toa, portanto, que o texto é finalizado com a inscrição INCIPIT ZARATUSTRA, numa referência explícita ao texto poético e dramático composto cerca de seis anos antes por Nietzsche. Também não é à toa que, nos extremos dessa "história", estejam justamente Platão e Nietzsche. De um lado, o jovem nobre e artista que teria queimado seus poemas e se convertido à dialética, tornando-se discípulo do decadente Sócrates, para, posteriormente, com a morte de seu mestre, retomar a pena para fazer de Sócrates um personagem que, com seu discurso dialético, no interior de um texto poético e dramático, cria a ficção de um "mundo verdadeiro" em oposição ao "mundo aparente", a ficção da filosofia como discurso verídico, em oposição à sofística e à poesia. Ficção que, paradoxalmente, acaba tendo como efeito uma aparente cisão entre o campo do conhecimento e o campo da arte. De outro lado, o jovem acadêmico, que teria se iniciado na filosofia, de um modo ainda tímido e um tanto reverente à tradição acadêmica e filosófica, mas, ainda assim, movido por um impulso antidialético, antissocrático, por um pendor artístico que não deixava de desembocar num elogio conceitual à arte; o jovem que posteriormente acabou por se afastar da academia, que acabou por desenvolver uma crítica radical à tradição de pensamento socrática, à tradição de pensamento platônica, através de textos que ostentam artifícios artísticos, literários, poéticos para levar à cabo a suspensão dos limites que separariam o "mundo verdadeiro" do "mundo aparente", a filosofia da ficção e, com isso, não só colocar abaixo a crença na velha verdade, como também investir na exaltação do eternamente cambiante reino das aparências - reino do qual a verdade só pode emergir, tal como 
teria emergido em meio aos textos de Platão: na condição de um mero acréscimo mentiroso.

\section{Referências bibliográficas}

NIETZSCHE, Friedrich. A gaia ciência. Tradução Paulo César Souza. São Paulo: Cia das Letras, 2001.

Além do bem e do mal. Tradução Paulo César Souza. São Paulo: Cia das Letras, 1992.

$\overline{\text { Brasileira, }}_{\text {Assim fa }}$ A98.

Crepúsculo dos ídolos. Tradução Paulo César Souza. São Paulo: Cia das Letras, 2006.

Ecce homo: como alguém se torna o que é. Tradução Paulo César Souza. São Paulo: Cia das Letras, 1995. 